dying, heart failure on admission, as determined clinically and radiologically, being nearly as likely to result in death from arrhythmia as in death from failure. Patients suffering late arrhythmic death were, however, much more ill than the survivors, having a greatly increased incidence of shock and heart failure, and a greater incidence of transmural infarction, particularly involving the anterior part of the heart. A detailed analysis of our 70 cases of late arrhythmic death showed that, excluding a few who had clearly diagnosable reinfarction, all but four had radiological evidence of interstitial or pulmonary oedema on admission, or heart failure, hypotension, or a major arrhythmia during the first few days after admission.

It is doubtful whether long-term E.C.G. monitoring of all patients at risk of late arrhythmic death is economically feasible or psychologically desirable, and it is probable that the yield in lives saved will be considerably less than by the institution of early intensive care as practised by Pantridge and his colleagues. It is also true that ventricular fibrillation complicating heart failure or shock has a poor prognosis in spite of monitoring and resuscitation (Robinson, 1965). Nevertheless, it is thought that arrhythmic death in patients who are recovering from circulatory failure is in many cases preventable with antiarrhythmic drugs, and the logical use of E.C.G. telemetry (Cerkez et al., 1965) is in this group of patients.

It is now our practice, in a four-bedded coronary care unit which has opened at Green Lane Hospital since this study was completed, to readmit patients who have had heart failure or major arrhythmia during their three to seven days of initial monitoring from the ward to the unit if their condition deteriorates. Warning signs of impending death from ventricular fibrillation are taken to be further chest pain not quickly relieved by trinitrin, a fall in blood pressure, or irregularity in the pulse which was not present before. Nurses are instructed to feel the pulse at the wrist of all coronary patients for a full minute and to report irregularities and ectopic beats. As late arrhythmic death occurs so seldom in uncomplicated cases, it can be argued that it is unnecessary to keep these patients in hospital for more than a week, and that mobilization and rehabilitation may be correspondingly accelerated.

We are grateful to the visiting physicians of Auckland, Green Lane, and Middlemore Hospitals for allowing patients under their care to be studied, and to the medical registrars for accurate recording of information. Dr. P. W. T. Brandt, radiologist to the cardiological and cardiothoracic surgical units at Green Lane Hospital, kindly reviewed all the chest $x$-ray films. Facilities for the transfer of data to punch cards and analysis of the results were provided by the medical statistics unit of the Auckland Hospital Board.

\section{REFERENCES}

Bainton, C. R., and Peterson, D. R. (1963). New Engl. F. Med., 268, 569.

Ball, C. O. T., Billings, F. T., jun., Furman, R. H., Brothers, G. B., Thomas, J., and Meneely, G. R. (1955). Circulation, 11, 749.

Beard, O. W., Hipp, H. R., Robins, M., Taylor, J. S., Ebert, R. V., and Beran, L. G. (1960). Amer. F. Med., 28, 871.

Billings, F. T., jun., Kalstone, B. M., Spencer, J. L., Ball, C. O. T., and Meneely, G. R. (1949). Amer. Ұ. Med., 7, 356.

Cerkez, C. T., Steward, G. C., and Manning, G. W. (1965). Canad. med. Ass. F., 93,1187

Doscher, N., and Poindexter, C. A. (1950). Amer. F. Med., 8, 623.

Grendahl, H. (1967). Acta med. scand., 181, 655.

Hilden, T., Iversen, K., Raaschou, F., and Schwartz, M. (1961). Lancet, 2. 327 .

Honey, G. E., and Truelove, S. C. (1957). Lancet, 1, 1155.

Killip, T. (1966). In The Current Status of Intensive Coronary Care. American College of Cardiology, New York.

London, R. E., and London, S. B. (1965). Circulation, 31, 202.

Lown, B., Fakhro, A. M., Hood, W. B., jun., and Thorn, G. W. (1967) 7. Amer. med. Ass., $199,188$.

Mintz, S. S., and Katz, L. N. (1947). Arch. intern. Med., 80, 205.

Mower, M. M., Miller, D. I., and Nachlas, M. M. (1964). Amer. Heart 7., 67, 437.

Norris, R. M. (1968). N.Z. med. F., 67, 470.

Norris, R. M., Caughey, D. E., and Scott, P. J. (1968). Brit. med. F., 2, 398.

Pantridge, J. F.; and Geddes, J. S. (1967). Lancet, 2, 271.

Pemberton, J., and McNeilly, R. H. (1967). Quoted by Pantridge and Geddes (1967).

Robinson, J. S. (1965). Amer. Hearı f., 69, 285.

Rosenbaum, F. F., and Levine, S. A.' (1941). Arch. intern. Med., 68, 913.

\title{
Organochlorine Pesticide Residues in Human Fat in Great Britain
}

\author{
D. C. ABBOTT,* B.SC., PH.D., F.R.I.C. ; R. GOULDING, † M.D., B.SC., M.R.C.P. ; J. O’G. TATTON,* M.SC., F.R.I.C.
}

\begin{abstract}
Cummary : In order to assess the trend in the body load $S$ of organochlorine pesticide residues in Great Britain, between July 1965 and June 1967 samples of fat were taken during routine necropsies on 247 subjects over 3 years old and on 44 stillborn or premature babies and infants below the age of 3 . The levels of the three main pesticides, B.H.C., dieldrin, and D.D.T., were lower than those found in an earlier survey carried out in 1963 and 1964. No marked differences were observed in levels throughout Britain, but the levels in man were higher than those in women. Britain compares favourably with other countries in which similar surveys have been done.
\end{abstract}

\section{Introduction}

The presence of organochlorine pesticide residues in human body tissues continues to attract considerable attention. Originally a matter of curiosity and concern, the determination of national mean concentration levels of these pesticides in

* Laboratory of the Government Chemist, London S.E.1.

+ Principal Medical Officer (Toxicology), Ministry of Health, London. human fat has now come to be regarded more as a method of measuring the degree of exposure to which a population is subjected. Useful information can be derived from each set of results and also from any trends that may become apparent from year to year. The effects of the general withdrawal from use of certain pesticides, or the introduction of new compounds into agricultural and veterinary practice, can be followed by such studies.

Between 1965 and 1967 at least 15 publications have appeared giving results of analyses of samples of human fat from such widespread sources as, for example, India (Dale et al., 1965), Israel (Wassermann et al., 1965), Denmark (Wiehe, 1966), New Zealand (Brewerton and McGrath, 1967), and New Orleans (Hayes et al., 1965). All of these papers tell much the same story; that these organochlorine pesticide residues are omnipresent. The papers differ, however, in reporting mean concentration levels, varying sometimes by orders of magnitude according to country.

In Britain an early study in 1961 was confined to Southeast England (Hunter et al., 1963). In 1963 and 1964 a further study, instigated by the Advisory Committee on Pesticides and Other Toxic Chemicals, was carried out jointly by 
the Ministry of Health and the Laboratory of the Government Chemist. This study covered selected centres in England and Wales (Egan et al., 1965). A second and larger joint study by these two bodies has now been carried out and the field has been extended to include Scotland. The results obtained are reported and discussed in this present publication.

\section{Experimental Methods and Materials}

Between July 1965 and June 1967247 samples of human perirenal fat, each of not less than $5 \mathrm{~g}$.; were collected from subjects over 3 years old during the course of routine postmortem examination by pathologists; one biopsy sample removed during surgical treatment of one of us was also examined. In addition, 44 further post-mortem samples were taken from either prematurely born or stillborn babies or from infants up to 3 years old.

All the specimens were placed in specially cleaned and prepared glass containers and stored at $-20^{\circ} \mathrm{C}$. while awaiting analysis.

Samples of fat were first freed from any non-fatty material and dried with cellulose tissue. The pesticide residues were extracted from the samples with hexane and cleaned-up by the method of de Faubert Maunder et al. (1964), which includes a dimethylformamide-hexane partition and passage through a column of prepared alumina. The final solutions were then examined by gas-liquid chromatography on silicone and Apiezon columns (Simmons and Tatton, 1967) using electroncapture detection. Results for some of the samples were confirmed by a thin-layer chromatographic method (Abbott et al., 1964).

\section{Results}

The 248 samples from subjects over 3 years old comprised 157 male and 91 female specimens. The results are summarized in Table I. As is usually the case in this work, the distributions tend to be skew, and the geometric means, which are likely to be more meaningful than the arithmetic means, have also been inserted.
Of the B.H.C. isomers found, beta-B.H.C. was predominant in all samples, usually to the extent of 90 to $95 \%$ of the total B.H.C., the remainder being the alpha and gamma isomers in roughly equal proportions. The ratio of $p p^{\prime}-$ D.D.T. to its initial breakdown product or metabolite, $p p^{\prime}$-D.D.E., varied with individual samples but in any particular grouping, whether by sex, geographic origin, or age group, was fairly constant at about 1 part $p p^{\prime}-$ D.D.T. to 2.6 parts of $p p^{\prime}$-D.D.E. A very similar ratio was obtained in a United States study (Hoffman et al., 1967) of 994 specimens taken in the Chicago area. Small amounts of $p p^{\prime}$-T.D.E., a further breakdown product of $p p^{\prime}$-D.D.T., were also observed in some samples, but overall it amounted to less than $2 \%$ of the total D.D.T. and its derivatives.

The variability between individual results did not differ significantly from that observed in the previous survey (Egan et al., 1965). Table II compares the results from that earlier work with those obtained in the present study. In Table II the results have been divided to show any differences attributable to sex. It is apparent that since 1964 there has been a decline in the mean levels for all the pesticide residues found in the human fat of both sexes in the U.K. This decline amounts overall by $1966-7$ to about $35 \%$ of the amounts found in $1963-4$ for for B.H.C. isomers, and about $20 \%$ for dieldrin and total D.D.T. Mean concentrations of B.H.C. isomers show little difference for the sexes but differentiation is more noticeable in the dieldrin results. It is even more marked when total D.D.T. results are compared, the male subjects showing levels about 50\% higher than females. Hoffman et al. (1967) obtained similar differences in the D.D.T. contents of men and women in the U.S.A.

The effect of geographical location is shown in Table III. For this purpose Great Britain was divided into three areas: England south of a line drawn from the Bristol Channel to the Wash, England north of this line and Wales, and Scotland. On the whole no significant differences can be seen between the results for the three areas. Differences, according to sex, in levels of D.D.T. compounds are perhaps greater in samples from Southern England, with only slight variations apparent with respect to the other pesticides. Results obtained in

TABle I.-Mean Pesticide Residue Levels in Human Fat in Great Britain (1965-7). 157 Male and 91 Female Subjects Over 3 Years Old (parts per million)

\begin{tabular}{|c|c|c|c|c|c|c|c|c|c|c|}
\hline & & & & & $\begin{array}{c}\text { Total } \\
\text { B.H.C. }\end{array}$ & $\begin{array}{c}\text { Heptachlor } \\
\text { Epoxide }\end{array}$ & Dieldrin & $p p^{\prime}$-D.D.E. & pp'-D.D.T. & $\begin{array}{l}\text { Total } \\
\text { D.D.T.* }\end{array}$ \\
\hline $\begin{array}{l}\text { Arithmetic mean } \quad . \\
\text { Range... } 0 \\
\text { Standard error of mean } \\
\text { Median value } \\
\text { Geometric mean } \quad \ldots \\
95 \% \text { confidence limits for }\end{array}$ & $\begin{array}{l}\ddot{\because} \\
\ddot{0} \\
\ddot{\text { geomet }}\end{array}$ & 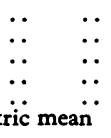 & $\begin{array}{l}\because \\
\because \\
\because \\
\therefore\end{array}$ & $\begin{array}{l}\because \\
\because \\
\therefore \\
\therefore\end{array}$ & $\begin{array}{c}0.31 \\
0.01-1 \cdot 88 \\
0.01 \\
0 \cdot 29 \\
0 \cdot 25 \\
0 \cdot 22-0 \cdot 27\end{array}$ & $\begin{array}{c}0.04 \\
0-0 \cdot 40 \\
= \\
=\end{array}$ & $\begin{array}{l}0 \cdot 21 \\
0-1 \cdot 0 \\
0 \cdot 01 \\
0 \cdot 20 \\
0 \cdot 17 \\
0 \cdot 15-0 \cdot 19\end{array}$ & $\begin{array}{c}2.0 \\
0.04-9.6 \\
= \\
=\end{array}$ & $\begin{array}{c}0.78 \\
0.03-3 \cdot 1 \\
= \\
=\end{array}$ & $\begin{array}{l}3 \cdot 0 \\
0 \cdot 08-13 \cdot 0 \\
0 \cdot 1 \\
2 \cdot 9 \\
2 \cdot 5 \\
2 \cdot 3-2 \cdot 7\end{array}$ \\
\hline
\end{tabular}

* The total D.D.T. has been calculated by adding the $p p^{\prime}-$ D.D.T. equivalent of the $p p^{\prime}-$ D.D.E. found to the $p p^{\prime}-$ D.D.T. found as such.

TABLE II.-Distribution of Organochlorine Pesticides in Human Fat by Sex and Period. $1965-6: 57$ males, 30 females. $1966-7$ : 100 males, 61 females (parts p'er million)

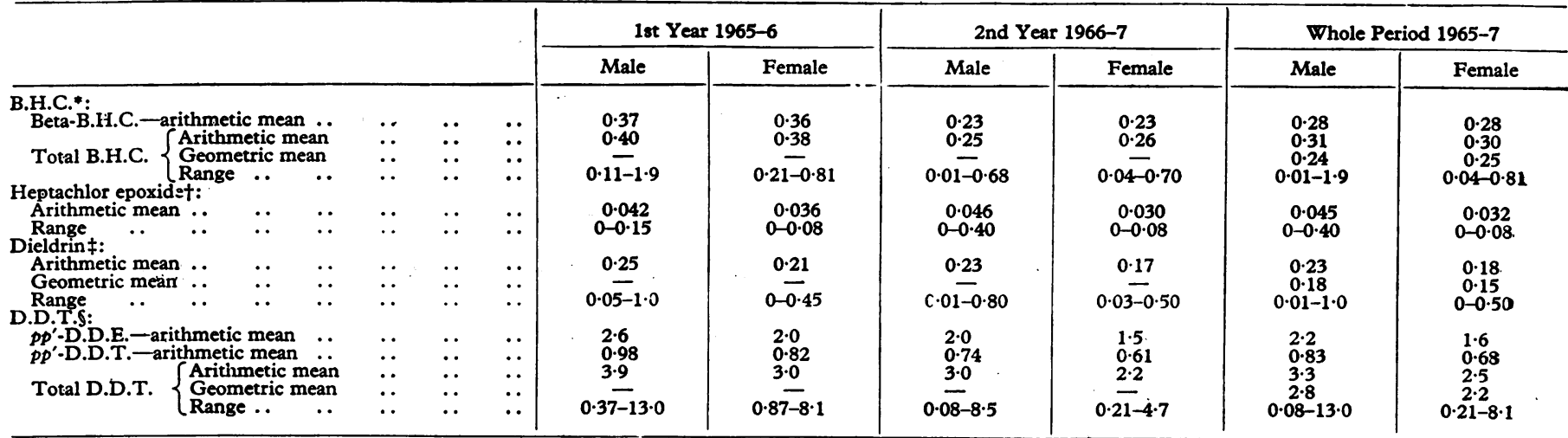

The arithmetic means for total B.H.C. isomers in the $1963-4$ survey (Egan et al., 1965) were: male 0.43 p.p.m., female 0.40 p.p.m.
$\dagger$ In the $1963-4$ survey (Egan et al., 1965 ), a trace of heptachlor epoxide, not exceeding 0.10 p.p.m. was detected in most samples of both sexes.

\# The arithmetic means for dieldrin in the 1963-4 survey (Egan et al., 1965) were: male 0.27 p.p.m., female 0.23 p.p.m.
(The arithmetic means for total D.D.T. in the 1963-4 survey (Egan et al., 1965) were: male 3.7 p.p.m., female 2.7 
Somerset in 1965 showed slightly higher dieldrin levels but lower results for D.D.T. and B.H.C. compounds (Cassidy et al., 1967).

TABLB III.-Mean Pesticide Residues in Human Pat by Geographical Location of Subjects (parts per million)

\begin{tabular}{|c|c|c|c|c|c|c|c|}
\hline & & \multicolumn{2}{|c|}{$\begin{array}{l}\text { Southern } \\
\text { England }\end{array}$} & \multicolumn{2}{|c|}{$\begin{array}{l}\text { Northern } \\
\text { England } \\
\text { and Wales }\end{array}$} & \multicolumn{2}{|c|}{ Scotland } \\
\hline & & Male & Female & Male & Female & Male & Female \\
\hline 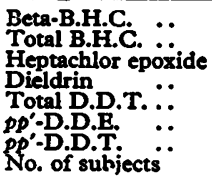 & 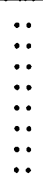 & $\begin{array}{l}0.27 \\
0.30 \\
0.05 \\
0.25 \\
3.4 \\
2.3 \\
0.85 \\
66\end{array}$ & $\begin{array}{l}0.28 \\
0.30 \\
0.03 \\
0.17 \\
2.2 \\
1.4 \\
0.64 \\
39\end{array}$ & $\begin{array}{l}0.29 \\
0.32 \\
0.04 \\
0.23 \\
3.2 \\
2.1 \\
0.80 \\
43\end{array}$ & $\begin{array}{l}0.33 \\
0.36 \\
0.03 \\
0.18 \\
2.3 \\
1.5 \\
0.59 \\
20\end{array}$ & $\begin{array}{l}0.28 \\
0.30 \\
0 \cdot 04 \\
0 \cdot 22 \\
3 \cdot 3 \\
2 \cdot 3 \\
0 \cdot 82 \\
48\end{array}$ & $\begin{array}{l}0.24 \\
0.25 \\
0.03 \\
0.18 \\
2.9 \\
1.9 \\
0.78 \\
32\end{array}$ \\
\hline
\end{tabular}

The observed distribution of the results by age, sex, and pesticide residue level is depicted in Table IV, in which the figures show the percentage of the total falling in each age group. The 41 to 60 age group contains the greatest percentage of the total having residues in the higher ranges.

Table IV.-Distribution of Pesticides in Human Fat by Age, Residue

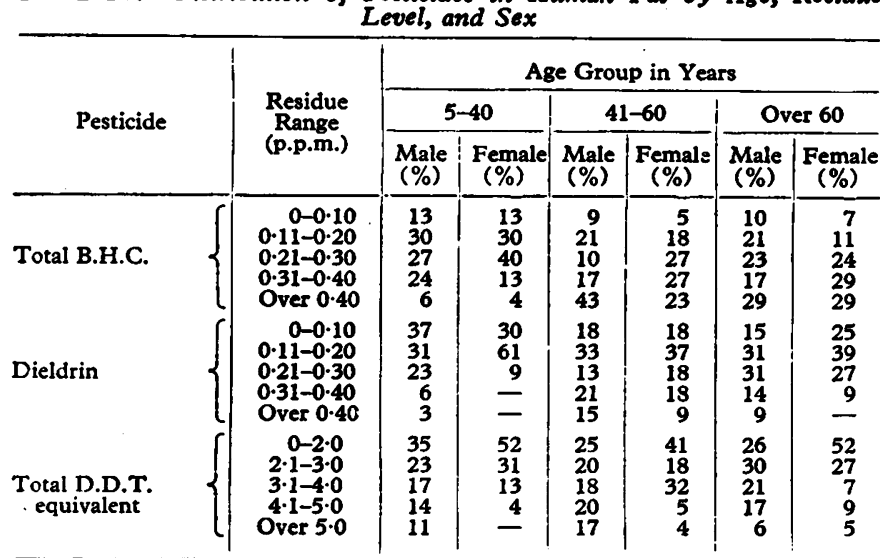

Table $\mathrm{V}$ gives the results of the analyses of samples from prematurely born or stillborn babies and infants under 3 years old. It is apparent that the foetus in the womb receives some of its mother's ingested pesticides through the placental barrier. This passage of organochlorine pesticides through the placental barrier to the foetus has been shown by Hathway (1965) to occur in rabbits. Thus the child starts its extrauterine life with significant concentrations of these pesticide residues already stored in its fat. There is a decline in these levels during the first three months after birth; this may be due in some measure to the rapid increase in fat content of the infant in the first months of its extrauterine life compared with the generally sparse fat of the foetus, the pesticides present at birth being thus dilutea. Such a decline could also be the result of a change to bottle-feeding on cow's milk rather than breastfeeding. Human breast milk contains substantially higher quantities of pesticides than cow's milk in Great Britain (Egan et al., 1965), so that any effects due to this change of feed would vary according to the source of the milk. It is also evident that subsequent transfer to a more adult diet leads to increases in the levels found.

\section{Conclusions}

It is gratifying to be able to record that the mean concentrations of the three main pesticides, B.H.C., dieldrin, and D.D.T., in the human body in Great Britain have decreased over the last few years. It is worth noting that a decline has also been observed concurrently in the levels of these organochlorine pesticide residues in fatty foods consumed in this country (Egan et al., 1966 ; Ministry of Technology, 1962-7). The decline in the dieldrin content of some of our home-produced foodstuffs is undoubtedly due to the abandonment in recent years of many of the previously approved uses of aldrin and dieldrin. It is significant that this observed decline of the B.H.C., dieldrin, and D.D.T. contents of our food has its parallel in their decline in our body fat and indicates that dietary sources are probably the main factor in determining the levels in human fat in this country.

It is difficult to account for the differences between the mean levels for the sexes except on the grounds that either males in general eat heavier and fattier meals than females or that women usually carry a larger amount of adipose tissue distributed over their persons than do men.

As mentioned earlier, the problem of organochlorine pesticide residues in human tissue is world-wide. Table VI compares the results of the present survey, for subjects over 3 years old, with those reported in recent years. It will be observed that while there is a general uniformity of dieldrin content at about the 0.2 p.p.m. level the D.D.T. results are much more variable.

TABLE VI.-Dieldrin and D.D.T. Residues in Human Fat in Various

\begin{tabular}{|c|c|c|c|c|c|c|c|}
\hline \multicolumn{8}{|c|}{ Countries } \\
\hline \multirow{2}{*}{\multicolumn{2}{|c|}{ Country }} & \multirow{2}{*}{ Period } & \multirow{2}{*}{$\begin{array}{l}\text { No. of } \\
\text { Samples }\end{array}$} & \multicolumn{3}{|c|}{ Mean Residues (p.p.m.) } & \multirow{2}{*}{ Ref. } \\
\hline & & & & Dieldrin & pp'-DDE & $p^{\prime}$-DDT & \\
\hline U.K. & $\bar{\cdots}$ & $1961 / 2$ & 131 & $0.21 *$ & - & - & Hunter et al. \\
\hline U.S.A. & .. & $1961 / 2$ & 30 & 0.15 & $3 \cdot 8$ & $1 \cdot 1$ & $\begin{array}{l}\text { Dale \& } \\
\text { Quinby } \\
\text { (1963) }\end{array}$ \\
\hline U.S.A. & .. & $1961 / 2$ & 130 & - & $7 \cdot 8$ & $4 \cdot 0$ & Quinby et al. \\
\hline U.S.A. & .. & $1962 / 3$ & 282 & - & $7 \cdot 4$ & 2.9 & $\underset{\text { al. (1964) }}{\text { Hoffman }}$ et \\
\hline U.S.A. & .. & $1962 / 3$ & 64 & 0.11 & - & - & Hoffman et \\
\hline U.K. & . & $1963 / 4$ & 65 & 0.26 & $2 \cdot 0$ & $1 \cdot 1$ & Egan et al. \\
\hline Israel & ․ & $1963 / 4$ & 254 & - & $10 \cdot 7$ & 8.5 & Wassermann \\
\hline India & $\cdot$. & 1961 & 24 & 0.03 & $11 \cdot 6$ & $13 \cdot 6$ & $\begin{array}{l}\text { et al. (1965) } \\
\text { Dale et al. } \\
\text { (1965) }\end{array}$ \\
\hline U.S.A. & . & 1964 & 25 & 0.29 & 6.9 & 1.7 & Hayes et al. \\
\hline U.K. & . & 1964 & 100 & 0.21 & $2 \cdot 3$ & 1.0 & $\begin{array}{l}\text { Robinson } \\
\text { al. (1965) }\end{array}$ \\
\hline Canada & $\cdots$ & 1966 & 27 & 0.22 & $2 \cdot 7$ & $1 \cdot 1$ & $\begin{array}{l}\text { Brown } \\
\text { (1967) }\end{array}$ \\
\hline U.K. & $\cdots$ & $1965-6$ & 101 & 0.23 & $1 \cdot 5$ & $1 \cdot 1$ & Cassidy et al. \\
\hline New Zeal & land & 1966 & 52 & 0.27 & 3.8 & 1.5 & $\begin{array}{l}\text { Brewerton } \\
\text { \& McGrath } \\
\text { (1967) }\end{array}$ \\
\hline $\begin{array}{l}\text { Denmark } \\
\text { U.S.A. }\end{array}$ & $\because$ & $\begin{array}{l}1966 \\
1966\end{array}$ & $\begin{array}{l}17 \\
71\end{array}$ & $\begin{array}{l}0.20 \\
0.22\end{array}$ & $\begin{array}{l}2.5 \\
6.7\end{array}$ & $\begin{array}{l}0.60 \\
2 \cdot 8\end{array}$ & $\begin{array}{l}\text { Weihe (1966) } \\
\text { Fiserova- } \\
\text { Bergerova } \\
\text { et }\end{array}$ \\
\hline $\begin{array}{l}\text { U.S.A. } \\
\text { U.K. }\end{array}$ & \{\} & $\begin{array}{l}1962 / 6 \\
1962 / 6 \\
1965 / 7\end{array}$ & $\begin{array}{l}994 \\
221 \\
248\end{array}$ & $\begin{array}{l}0 . \overline{14} \\
0.21\end{array}$ & $\frac{7.0}{2.0}$ & $\frac{2.6}{0.78}$ & $\begin{array}{l}\text { Heffman } \\
\text { et al.(1967) } \\
\text { This paper }\end{array}$ \\
\hline
\end{tabular}

Thus in India and Israel, where much D.D.T. is used for public health reasons, the levels of total D.D.T. equivalent are about 20 p.p.m. In the U.S.A., where D.D.T. has a widespread pesticide usage, about 8 to 10 p.p.m. of D.D.T. compounds are found in human fat.

Table V.-Organochlorine Pesticide Residues in Fat of Infants Under 3 Years Old-1965-7 (parts per million)

\begin{tabular}{|c|c|c|c|c|c|c|c|c|c|c|}
\hline \multicolumn{3}{|c|}{ Age Group } & $\begin{array}{l}\text { No. of } \\
\text { Samples }\end{array}$ & & Beta-B.H.C. & Total B.H.C. & Dieldrin & pp'-D.D.E. & pp'-D.D.T. & Total D.D.T. \\
\hline $\begin{array}{l}\text { Prematurely born, } \\
\text { within } 24 \text { hours }\end{array}$ & $\begin{array}{l}\text { stillborn } \\
\text {.. }\end{array}$ & $\begin{array}{c}n \text {, or died } \\
. .\end{array}$ & 23\{ & $\begin{array}{l}\text { Arithmetic mean } \\
\text { Range }\end{array}$ & 0.12 & $\begin{array}{l}0.13 \\
0.0 .55\end{array}$ & 0.09 & $\stackrel{0.65}{0.07-1.8}$ & 0.24 & $\begin{array}{c}0.96 \\
0.12-2 \cdot 6\end{array}$ \\
\hline 1 day to 3 months & $\cdot$ & $\cdots$ & 11\{ & $\begin{array}{l}\text { Arithmetic mean } \\
\text { Range }\end{array}$ & $\begin{array}{c}0.10 \\
0.02-0.31\end{array}$ & $\begin{array}{c}0.13 \\
0.03-0.31\end{array}$ & $\begin{array}{c}0.07 \\
0.02-0.17\end{array}$ & $\begin{array}{c}0.48 \\
0.04-1 \cdot 2\end{array}$ & $0.05-0.40$ & $\begin{array}{c}0.72 \\
0-09-1 \cdot 7\end{array}$ \\
\hline 3 months to 1 year & - & $\cdots$ & 10\{ & $\begin{array}{l}\text { Arithmetic mean } \\
\text { Range }\end{array}$ & $\begin{array}{l}0.12 \\
0.04-0.30\end{array}$ & $\begin{array}{c}0.15 \\
0.06-0.36\end{array}$ & $\begin{array}{l}0.11 \\
0.04-0.30\end{array}$ & $\stackrel{0.50}{0.15-0.90}$ & $\stackrel{0.26}{0.08-0.70}$ & $\stackrel{0-81}{0.25-1.6}$ \\
\hline
\end{tabular}


Thus, compared with most other countries in which similar studies have been made, D.D.T. residues in human fat in Great Britain remain at a very low level, and indeed there has been an apparent decline in the general levels of all the pesticide residues. This could be regarded as a comparatively satisfactory state of affairs.

We should like to thank those pathologists throughout the country who have helped by providing samples and those members of the staff of the Laboratory of the Government Chemist who have assisted in the analysis of the samples. Thanks are also due to Mr. O. F. Newman for the statistical analyses. This report is published by permission of the Government Chemist (Ministry of Technology) and the Ministry of Health.

\section{REFERENCES}

Abbott, D. C., Egan, H., and Thomson, J. (1964). J. Chromatogr., 16,

Brewerton, H. V., and McGrath, H. J. W. (1967). N.Z. Y. Sci., 10, 486. Brown, J. R. (1967). Canad. med. Ass. 7., 97, 367.
Cassidy, W., Fisher, A. J., Peden, J. D., and Parry-Jones, A. (1967). Mih. Bull. Minist. Hlth Lab. Serv., 26,2

Dale, W. E., Copeland, M. F., and Hayes, W. J. (1965). Bull. Wld Hlth Org., 33, 471 .

Dale, W. E., and Quinby, G. E. (1963). Science, 142, 593.

Egan, H., Goulding, R., Roburn, J., and Tatton, J. O'G. (1965). Brit. med. $\}_{\text {., }} 2,66$.

Egan, H., Holmes, D. C., Roburn, J., and Tatton, J. O'G. (1966). 7 Sci. Food Agric., 17, 563.

de Faubert Maunder, M. J., Egan, H., Godly, E. W. Hammond, E. W. Roburn, J., and Thomson, J. (1964). Analyst, 89, 168.

Fiserova-Bergerova, V., Radomsti, J. L., Davies, J. E., and Davis, J. H (1967). Industr. Med. Surg., 36, 65

Hathway, D. E. (1965). Arch. environm. Hith, 11, 380

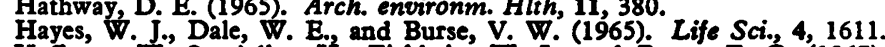

Hoffman, W.' S., Adler, H., Fishbein, W. I., and Bauer, F. C.. (1967). Arch. environm. Hlth, 15, 758 .

Hoffman, W. S., Fishbein, W. I., and Andelman, M. B. (1964). Arch. environm. Ḧlth, 9, 387 .

Hunter, C. G., Robinson, J., and Richardson, A. (1963). Brit. med. \%. 1, 221 .

Ministry of Technology (1962-7). Annual Reports of the Government Chemist. H.M.S.O., London.

Quinby, G. E., Hayes, W. J., Armstrong, J. F., and Durham, W. F. (1965). Y., Amer med. Ass., 191, 175.

Robinson, J., Richardson, A., Hunter, C. G., Crabtree, A. N., and Rees, H. J. (1965). Brit. \%. industr. Med., 22, 220.

Simmons, J. H., and Tatton, J. O'G. (1967). J. Chromatogr., 27, 253.

Wassermann, M., Gon, M., Wassermann, D., and Zellermayer, L. (1965) Arch environm. Hith, 11, 375

Weihe, M. (1966). Ugeskr. Lag., 128, 881.

\title{
Tinea Incognito
}

\section{F. ADRIAN IVE,* M.B., M.R.C.P. ; RONALD MARKS,* M.B., B.SC., M.R.C.P., D.T.M.\&H.}

\author{
Brit. med. F., 1968, 3, 149-152
}

\begin{abstract}
Cummary : Fourteen cases are described in which the $\checkmark$ local application of corticosteroid preparations to ringworm infections of the skin have resulted in unusual clinical pictures. A kerion-like lesion due to Trichophyton rubrum, intertriginous infections simulating candidiasis and due to Epidermophyton floccosum, and pictures resembling poikiloderma, papular rosacea, and indeterminate leprosy are among the changes that were seen in these patients.
\end{abstract}

\section{Introduction}

Dermatology has been greatly helped in recent years by the introduction of a variety of potent therapeutic agents. While this has often meant that diseases are easier to control it has also resulted in an increase of iatrogenic disease.

Corticosteroid ointments tend to be used as a dermatological panacea and the misuse of these powerful agents is often the cause of commonly observed iatrogenic skin disease. While the frequently disastrous results of the systemic abuse of corticosteroids have been well documented there are few references to the problems that result from their inappropriate topical application (Grice, 1966).

Dermatologists have become increasingly aware that the clinical appearance of some rather common skin diseases may be rendered almost unrecognizable by topical steroids and particularly by the use of their fluorinated derivatives. This applies especially to those dermatoses in which the use of these compounds is normally contraindicated.

A principal action of corticosteroids is to suppress inflammation, and when administered systemically they can hinder immune responses. In this way they may contribute significantly to the morbidity of infective disease of all types, specific examples being bacterial infections such as tuberculosis,

* Senior Registrar, St. John's Hospital for Diseases of the Skin, London W.C.2. viral infections such as chicken-pox, and fungal diseases such as ringworm (Kligman, Baldridge, Rebell, and Pillsbury, 1951). Extensive tinea corporis is a well-documented complication of Cushing's disease (Canizares, Shatin, and Kellert, 1959). Thus it is surprising to find that corticosteroids are not infrequently used in the management of infective skin disease. This situation probably derives in part from the tendency of patients to indulge in self-medication with hoarded ointments. In most instances, however, it would appear to stem from the recognition, by doctors, of the undoubted ability of steroids to provide prompt relief of symptoms by the suppression of inflammation. Systemic immune responses can usually contain the infection, and patient satisfaction is assured. This appertains especially in herpes simplex, when the risk of promoting keratitis is often disregarded.

Impetigo, scabies, and specifically ringworm infections are also often mistakenly treated by local corticosteroid preparations and sometimes even by systemic administration. The bizarre clinical pictures which ensue can tax the most expert diagnostician. The following cases illustrate the difficulties resulting from the use of local corticosteroids in the treatment of superficial fungus infections.

\section{Case Reports}

Case 1.-A West Indian woman aged 31 complained of an irritating rash that started in the groins and spread to the adjoining thighs. She had been given Synalar (fluocinolone acetonide) and Betnovate (betamethasone-17-valerate), which brought transient symptomatic relief only. On examination there were well-defined patches which were non-scaly, depigmented, purplish, and telangiectatic. Fungal mycelium was seen in a scraping of the involved skin and Epidermophyton floccosum was grown from skin scales. She was treated with half-strength Whitfield's ointment and was clear after three weeks.

Case 2.-A woman aged 71 had a rash on the feet and ankles for the previous year. She had used betamethasone under poly- 